\title{
Kontribusi Lamun Enhalus acoroides Terhadap Kelimpahan Perifiton Di Perairan Legon Boyo, Karimunjawa
}

\author{
Hendrayana $^{1}$, Ambariyanto $^{2}$, Delianis Pringgenies ${ }^{2}$, Mujiyanto ${ }^{3}$ \\ ${ }^{1}$ Fakultas Perikanan dan Ilmu Kelautan, Universitas Jenderal Soedirman \\ Jl. Prof. Dr. HR. Boenjamin 708 Kotak Pos 115 Purwokerto Jawa Tengah, 53122 \\ ${ }^{2}$ Fakultas Perikanan dan Ilmu Kelautan, Universitas Diponegoro \\ Jl. Prof. Soedarto, SH, Tembalang, Semarang, Jawa Tengah, 50275 \\ ${ }^{3}$ Balai Riset Pemulihan Sumber Daya Ikan \\ Jl. Cilalawi No.1 Jatiluhur, Jatimekar, Purwakarta, Jawa Barat 41152 \\ Email: hendrayana@unsoed.ac.id
}

\begin{abstract}
Abstrak
Kelimpahan perifiton dipengaruhi oleh kerapatan lamun karena pada semakin tinggi kerapatan lamun maka kecepatan arus akan berkurang sehingga dapat meningkatkan laju penempelan perifiton. Penelitian ini bertujuan untuk mengetahui hubungan kerapatan lamun Enhalus acoroides dengan kelimpahan perifiton di Perairan Legon Boyo, Karimunjawa Penelitian ini menggunakan metode deskriptif dan pengambilan sampel menggunakan metode purposive sampling. Penelitian dilakukan pada bulan Juni, September dan Desember Tahun 2012. Hasil penelitian menunjukkan bahwa perifiton yang ditemukan pada lamun Enhalus acoroides di Perairan legon sebanyak 10 jenis dan jenis Baciliarophyceae merupakan jenis perifiton paling banyak ditemukan. Kelimpahan terbesar terjadi di musim peralihan yaitu sebesar $2.146 \mathrm{sel} / \mathrm{l}$. Keanekaragaman jenis perifiton di lamun E. acoroides memiliki nilai antara 0,26-1,43 (Keanekaragaman rendah-sedang), keseragaman dengan nilai 3,61-5,82 (keseragaman tinggi) dan dominansi dengan nilai 0,68-1,12 (dominansi sedang-tinggi). Hasil analisis regresi hubungan kerapatan lamun dengan kelimpahan perifiton sebesar $79,13 \%$ yang menunjukkan hubungan kuat. Dengan demikian kerapatan lamun berpengaruh terhadap kelimpahan perifiton pada lamun.
\end{abstract}

Kata kunci : Perifiton, Lamun, Enhalus acoroides, Kelimpahan, Karimunjawa

\section{Abstract \\ Contribution of Seagrass Density for Periphyton Abudance}

Periphyton abudance is influence by Seagrass densit. The aim of the research was to determaine Enhalus acoroides seagrass density and periphyton abudance correlation in Legon Boyo, Karimunjawa waters. Descriptive method and purposive sampling used in the research. The result show perphyton found as 10 kinds ang Baciliarophyceae clases are most of periphyton found. The most abundant periphyton in the transitional season is 2,146 cells/l. Periphyton species diversity in E.acoroides seagrass has a value between 0.26-1.43 (low-moderate diversity), uniformity with a value of 3.61-5.82 (high uniformity) and dominance with a value of 0.68-1.12 (moderate-high dominance). Correlation relationship with periphyton abundance was $79.13 \%$, which showed a strong relationship. This value show of seagrass density influence periphyton abudance in seagrass.

Keywords : Periphyton, Seagrass, Enhalus acoroides, Abudance, Karimunjawa

\section{PENDAHULUAN}

Lamun merupakan ekosistem laut perairan dangkal yang memiliki fungsi ekologis sebagai penghasil unsur hara, habitat bagi berbagai organisme dan perangkap sedimen (Nabilla et al.,
2019). Fungsi ini mendukung lamun dalam menjaga Keanekaragaman dan kelestarian organisme laut (Riniatsih, 2016). Keanekaragaman organisme lamun dapat diamati dari keberadaan berbagai organisme laut yang memanfaatkan 
lamun sebagai habitat. Salah satu organisme tersebut adalah perfiton.

Perifiton merupakan kumpulan organisme diatom yang menempel pada suatu organisme tertentu (Odum, 1993). Keberadaan organisme perifiton pada lamun dapat ditemukan dalam permukaan daun maupun akar lamun. Perifiton biasanya dicirikan dengan sekumpulan organisme yang berwarna coklat dan terlihat mengkilap sehingga organisme ini sering dikategorikan organisme biofilm (Odum, 1993).

Perifiton umumnya merupakan produsen primer sehingga keberadaan organisme ini berperan penting pada struktur tropik level ekosistem lamun (Febriana et al., 2016). Fungsi penting ini menjadikan perifiton sebagai salah satu bioindikator penting dalam menentukan tingkat kesehatan perairan dan indikator pencemaran perairan (Odum, 1993).

Kelimpahan perifiton tinggi akan mendukung produktifitas perairan di ekosistem lamun. Kolonisasi perifiton yang melimpah di permukaan daun lamun akan mendorong percepatan pembusukan daun lamun. Menurut Orbita dan Mukai (2013) kondisi lamun dapat terganggu akibat kelimpahan perifiton yang terlalu tinggi. Proses kolonisasi perifiton dipengaruhi oleh kondisi arus di sekitar lamun. Kecepatan arus akan semakin rendah ketika berada pada lamun dengan kerapatan tinggi sehingga proses penempelan perifiton pada lamun akan semakinmeningkat. Kerapatan lamun di suatu perairan akan menentukan tingkat kelimpahan perifiton (Aparna dan Yadav, 2008).

Perairan Legon Boyo, Karimunjawa merupakan perairan yang menjadi habitat bagi beberapa jenis lamun, seperti Enhalus acoroides. Perairan ini memiliki morfologi menjorok seperti teluk dan memiliki tipe substrat substrat pasir berlumpur. Enhalus acoroides merupakan jenis lamun yang hidup pada substrat pasir berlumpur, lumpur lunak dan lumpur tertutup karang (Sakey et al., 2015). Lamun jenis ini biasanya ditemukan dominan di suatu perairan. Keberadaan lamun ini mendukung bagi kehidupan berbagai organisme laut seperti ikan. Menurut Hapsari et al (2013) terdapat 16 famili dan 42 spesies ikan di ekosistem lamun dan beberapa diantaranya memiliki nilai ekonomis seperti Siganus sp. Keberadaan organisme disuatu pperairan biasanya menjadi indikator bahwa di perairan tersebut memiliki nutrien dan makanan yang mendukung kehidupan suatu organisme. Perifiton merupakan salah satu organisme yang menghasilkan bahan organik di ekosistem lamun, sehingga keberadaan perifiton pada setiap lamun memiliki kontribusi bagi organisme di ekosistem tersebut. Penelitian ini bertujuan untuk mengetahui hubungan kerapatan Enhalus acoroides dengan kelimpahan perifiton di Perairan Legon Boyo, Karimunjawa.

\section{MATERI DAN METODE}

Materi penelitian ini berupa perifiton yang diambil dari lamun jenis E. acoroides. Pengambilan sampel dilakukan bulan Juni, September dan Desember Tahun 2012 di Perairan Legon Boyo, Karimunjawa. Referensi ilmiah tentang penelitian perifiton lamun di Legon Boyo masih sangat sedikit, sehingga materi ini masih relevan untuk dipublikasikan. Metode penelitian ini adalah metode deskriptif dengan pengambilan sampel menggunakan metode purposive sampling. Pengambilan sampel dilakukan pada lokasi yang secara visual memiliki kerapatan lamun sedang hingga tinggi. Parameter perairan yang diamati dalam penelitian ini adalah suhu, kecerahan, nitrat, nitrit, fosfat, $\mathrm{BO}$, salinitas, $\mathrm{pH}$, dan $\mathrm{DO}$.

Sampel perifiton diambil dengan cara memilih daun lamun pada subtransek. Pengambilan sampel perfiton (Sarbini et al., 2015) dilakukan sebagai berikut: Setiap subtransek dipilih 3-5 tegakan lamun; Daun lamun yang memiliki warna kecoklatan dipilih; Daun diambil dengan cara diukur panjang daun sekitar $10 \mathrm{~cm}$ lalu dipotong dengan menggunakan gunting; Daun yang telah dipotong lalu dikerik dengan pelan-pelan untuk diambil perifitonnya; Sampel perifiton dimasukkan ke dalam botol sampel lalu ditambahkan formalin $4 \%$; Sampel perifiton dibawa ke laboratorium untuk diamati dengan menggunakan mikroskop.

Kelimpahan perifiton dihitung rumus sebagai berikut (APHA, 1989). Keanekaragaman jenis perifiton dihitung dengan menggunakan indeks Shannon - Wiener. Dengan nilai indeks H' $<1$ : Kenekaragaman jenis rendah; $1<\mathrm{H}^{\prime}<3$ : Keanekaragaman jenis sedang; $\mathrm{H}^{\prime}>3$ : Keanekaragaman jenis tinggi. Keseragaman Jenis (E): Indeks keseragaman perifiton dihitung menggunakan indeks Shannon - Wiener, Dengan nilai indeks $\mathrm{E}<0,4$ : Keseragaman jenis rendah; $0,4<\mathrm{E}<0,6 \quad$ : Keseragaman jenis sedang; $\mathrm{E}>$ 0,6 : Keseragaman jenis tinggi. Indeks dominansi (C) dapat diketahui dengan rumus:

$$
\mathrm{C}=\sum_{k=0}^{n} \mathrm{p}_{\mathrm{i}^{2}} \text { atau } \sum_{\mathrm{k}=0}^{\mathrm{n}}\left(\frac{\mathrm{n}_{\mathrm{i}}}{\mathrm{N}}\right)^{2}
$$

Keterangan : $\mathrm{C}=$ Indeks dominansi Simpson; $\mathrm{n}=$ Jumlah individu jenis ke-i; $\mathrm{N}=$ Jumlah seluruh individu. 


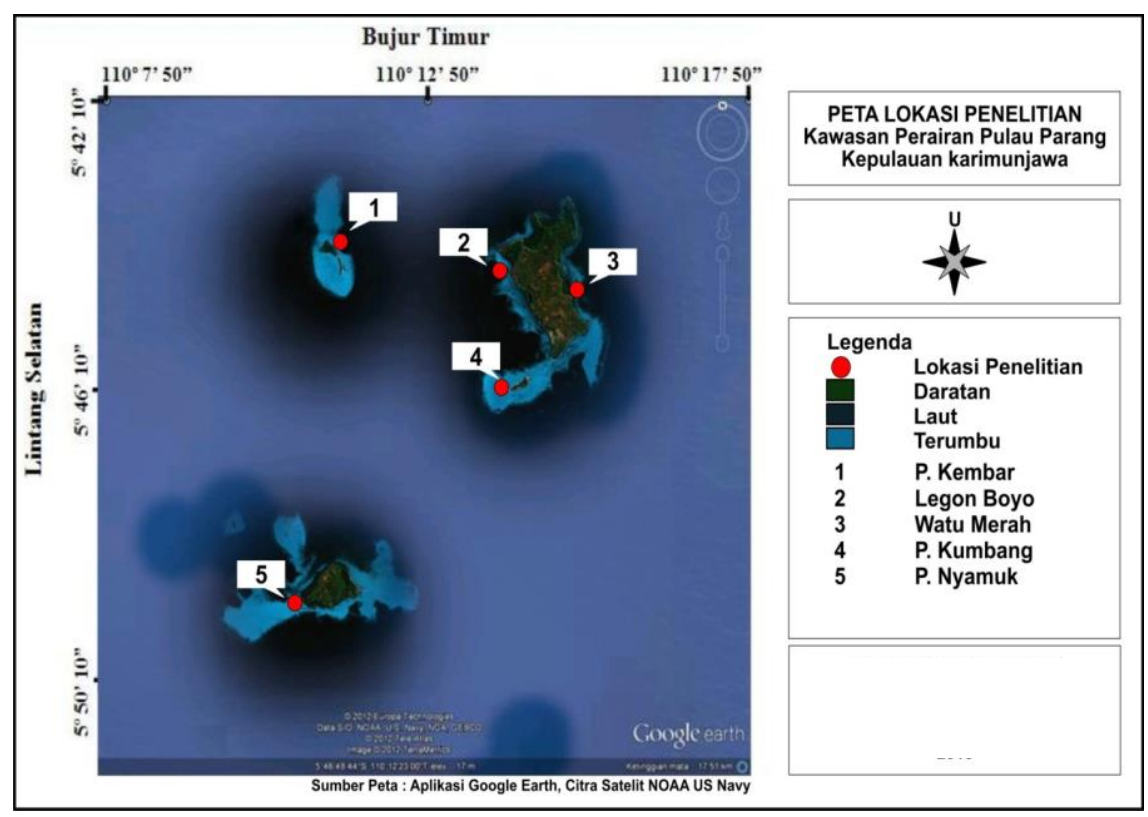

Gambar 1. Lokasi pengambilan Sampel Perifiton di Legon Boyo

Nilai hasil indeks di terjemahkan pada kriteria < $0,5=$ Dominasi rendah; $0,5<\mathrm{C}<1=$ Dominasi sedang; $\mathrm{C}>1=$ Dominasi tinggi.

\section{Analisis Regresi}

Analisis regresi digunakan untuk mengetahui hubungan antara kerapatan lamun dengan kelimpahan perifiton. Analisis regresi merupakan analisis yang digunakan untuk mengetahui hubungan antara perifiton (Y) dengan kerapatan lamun (X). Analisis ini dilakukan untuk mengetahui hubungan antara kelimpahan perifiton dengan kerapatan lamun (Usman dan Akbar. 2000).

$$
\mathbf{Y}=\mathbf{a}+\mathbf{b X} \text { (linier) }
$$

Keterangan $: \mathrm{Y}=$ Nilai pengamatan kelimpahan perifiton; $\mathrm{a}=$ Konstanta; $\mathrm{X}=$ Nilai pengamatan kerapatan lamun; $\mathrm{b}=$ Konstanta

\section{HASIL DAN PEMBAHASAN}

Kehadiran perifiton pada Lamun Jenis $E$. acoroides di Perairan Legon Boyo menunjukkan bahwa kehadiran perifiton pada musim peralihan paling banyak ditemukan yaitu sebanyak 8 jenis (Tabel 1). Kehadiran ini diikuti kelimpahan perifiton tertinggi di musim peralihan yaitu sebanyak 616 sel/l (Tabel 2). Kelas Bacillaryophyceae merupakan kelas yang paling banyak ditemukan di setiap musim. Bacillariophyceae merupakan diatom perintis yang ditemukan sebagai penyusun utama komunitas perifiton. Kelas ini didominasi oleh diatom dan fitoplankton seperti Navicula sp. dan Nitszchia sp. Bacillariophyceae merupakan epifit penyusun utama pada lamun terutama jenis Cocconeis sp., Navicula sp. dan Nitszchia sp. Hal ini terkait dengan sifat Bacillariophyceae sebagai biota kosmopolit yang mampu beradaptasi pada semua kondisi perairan (Siregar dan Telaumbanua, 2010).

Perifiton pada lamun juga ditemukan pada lamun jenis E. acoroides pada setiap musim adalah perifiton jenis Cyanophyceae dan Dynophyceae. Perifiton jenis Sarcodina, Nematoda dan Polychaeta ditemukan dalam jumlah sedikit. Barus et al., (2019) menyatakan bahwa organisme cacing hidup pada substrat berlumpur dikarenakan substrat lumpur memiliki sumber makanan dan menganduk bahan organik melimpah.

\section{Kelimpahan Perifiton}

Kelimpahan perifiton lamun E. acoroides di Perairan Legon Boyo, Karimunjawa menunjukkan bahwa kelimpahan tertinggi di musim peralihan yaitu $2.146 \mathrm{sel} / \mathrm{l}$ dan terendah pada musim barat yaitu $985 \mathrm{sel} / \mathrm{l}$. Kelimpahan lamun dipengaruhi oleh beberapa faktor seperti substrat dan luas penampang lamun. Kondisi substrat Legon Boyo berlumpur menyebabkan proses pengadukan biasanya lebih mudah terangkat dan menempel pada lamun. Proses pengadukan ini disebabkan oleh pergerakan arus di perairan tersebut (Ario et al., 2019). 
Tabel 1. Kehadiran Perfiton pada Lamun Jenis E. acoroides di Perairan Legon Boyo

\begin{tabular}{|c|c|c|c|}
\hline \multirow{2}{*}{ Kelas } & \multicolumn{3}{|c|}{ Musim } \\
\hline & Timur & Peralihan & Barat \\
\hline Bacillaryophyceae & + & + & + \\
\hline Chlorophyceae & + & 0 & + \\
\hline Cyanophyceae & + & + & + \\
\hline Dinophyceae & + & + & + \\
\hline Fragilariaophyceae & - & + & - \\
\hline Myxophyceae & + & - & + \\
\hline Nematoda & - & + & + \\
\hline Sagittoidea & - & + & - \\
\hline Polychaeta & - & + & - \\
\hline Crustacea & - & + & - \\
\hline
\end{tabular}

Tabel 2. Frekuensi Jenis Perifiton pada Lamun E. acoroides di Perairan Legon Boyo

\begin{tabular}{lccc}
\hline \multirow{2}{*}{ Kelas } & \multicolumn{2}{c}{ Musim } & Barat \\
\cline { 2 - 4 } & Timur & Peralihan & 248 \\
\hline Bacillaryophyceae & 367 & 572 & 7 \\
Chlorophyceae & 24 & 0 & 10 \\
Cyanophyceae & 22 & 3 & 12 \\
Dinophyceae & 12 & 18 & 0 \\
Fragilariaophyceae & 0 & 9 & 7 \\
Myxophyceae & 10 & 0 & 3 \\
Nematoda & 0 & 7 & 0 \\
Sagittoidea & 0 & 1 & 0 \\
Polychaeta & 0 & 1 & 0 \\
Crustacea & 0 & 5 & 287 \\
\hline JUMLAH & 435 & 616 & \\
\hline
\end{tabular}

Tabel 3. Kerapatan Lamun di Perairan Legon Boyo

\begin{tabular}{lrrr}
\hline \multirow{2}{*}{ Nama Spesies } & \multicolumn{3}{c}{ Legon Boyo } \\
\cline { 2 - 4 } & Timur & Peralihan & \multicolumn{1}{c}{ Barat } \\
\hline Cymodocea rotundata & 0 & 0 & 1,88 \\
Enhalus acoroides & 65,63 & 55,16 & 60,21 \\
Halodule pinifolia & 0 & 1,07 & 0 \\
Halodule uninervis & 0 & 0,67 & 0 \\
Halophila ovalis & 3,26 & 13,8 & 4,02 \\
Thalassia hemprichii & 20 & 29,3 & 33,89 \\
\hline
\end{tabular}

Proses penempelan ini biasanya paling banya ditemukan pada daun lamun. E. acoroides merupakan lamun yang memiliki tegakan tertinggi dibanding jenis lamun lain. Kondisi ini menyebabkan E.acoroides rata - rata memiliki kelimpahan perifiton paling tinggi dibandingkan jenis lamun lainnya. berdasarkan data lapangan juga ditemukan lamun jenis Thalassia 
hemperichii dengan kelimpahan perifiton tertinggi sebesar 1.566 sel/l. Keberadaan perifiton di daun lamun ini juga digunakan sebagai pendukung proses fotosintesis perifiton. Perifiton umumnya merupakan produsen primer yang mampu memproduksi unsur hara sehingga keberadaan organisme ini berperan penting pada struktur tropik level ekosistem lamun (Febriana et al., 2016).

Keanekaragaman jenis perifiton di lamun E. acoroides memiliki nilai antara 0,26-1,43 (Keanekaragaman rendah-sedang), keseragaman dengan nilai 3,61-5,82 (keseragaman tinggi) dan dominansi dengan nilai 0,68-1,12 (dominansi sedang-tinggi). Kondisi ini menunjukkan bahwa persebaran jenis perifiton tidak merata sehingga keseragaman dan dominansi dalam kategori tinggi (Odum, 1993).
Keanekaragaman perifiton ini dapat disebabkan karena proses kolonisasi berlangsung dalam waktu lama dan proses pergantian jenis berjalan dengan lambat. Hal ini dapat disebabkan karena kontur Legon Boyo merupakan daerah cekungan sehingga arus memiliki kecepatan rendah. Keseragaman dan dominansi tertinggi di musim timur yang memiliki kondisi perairan relatif tenang dengan sinar matahari maksimal. Keberadaan sinar matahari memaksimalkan produktivitas perairan dalam melakukan proses dalam memproduksi unsur hara. Sedangkan dominansi paling rendah di musim barat disebabkan karena arus di perairan ini cukup besar sehingga sirkulasi pergantian jenis perifiton berkangsung lebih cepat. Akumulasi perifiton meningkat pada perairan berarus kuat (Welch, 1981).

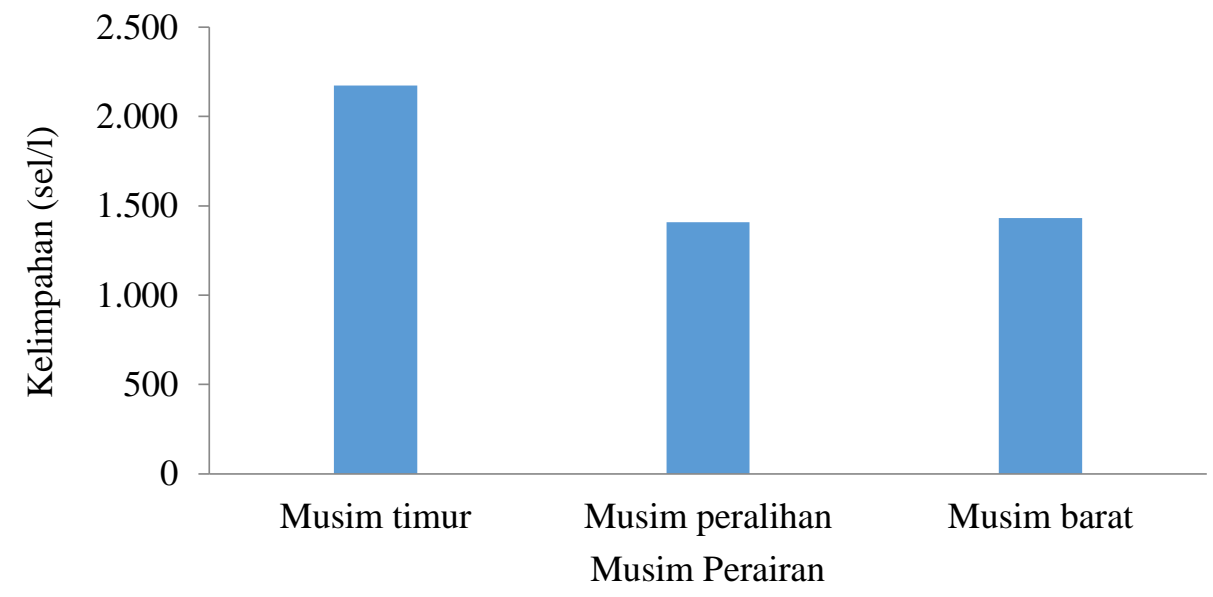

Gambar 2. Kelimpahan Perifiton pada Lamun E. acoroides di Perairan Legon Boyo (sel/l)

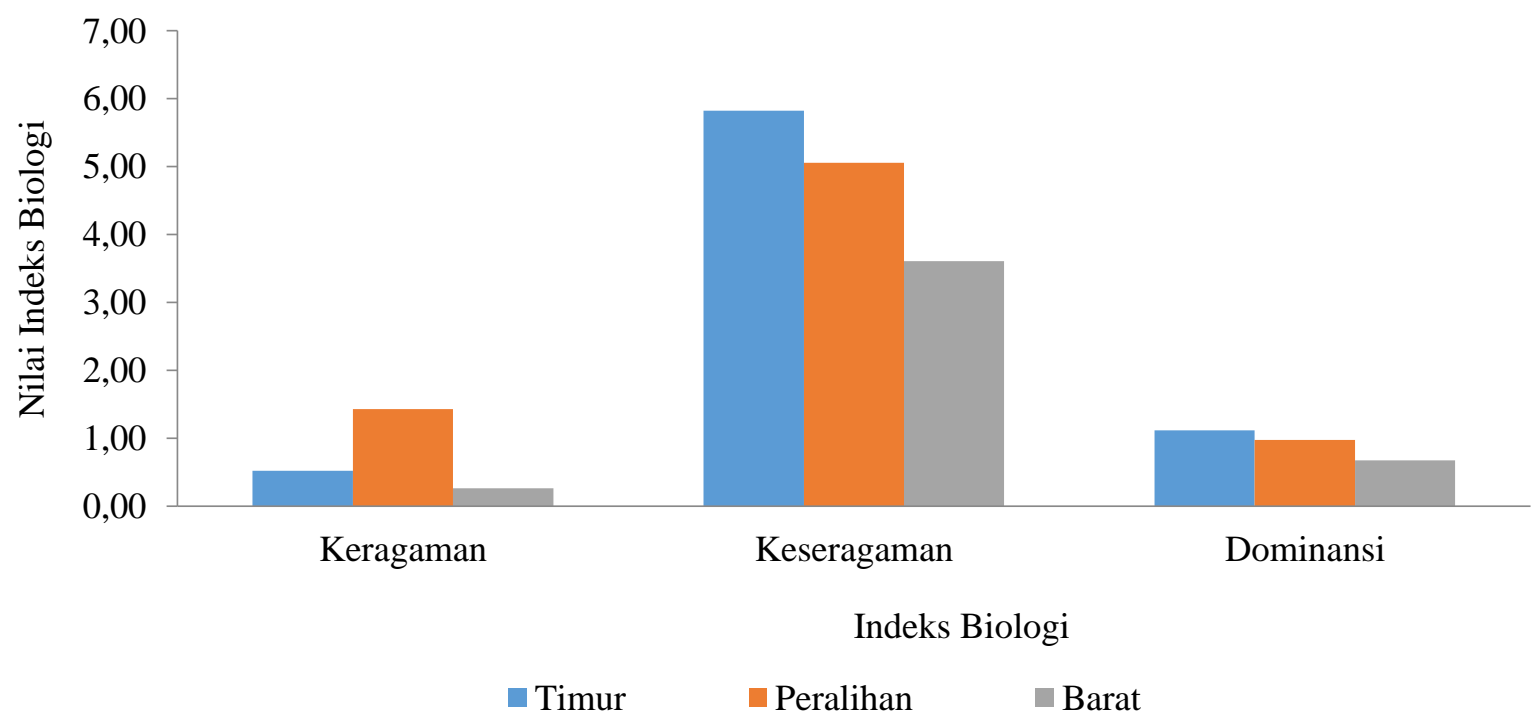

Gambar 3. Indeks Biologi Perifiton pada Lamun E. acoroides di Perairan Legon Boyo 


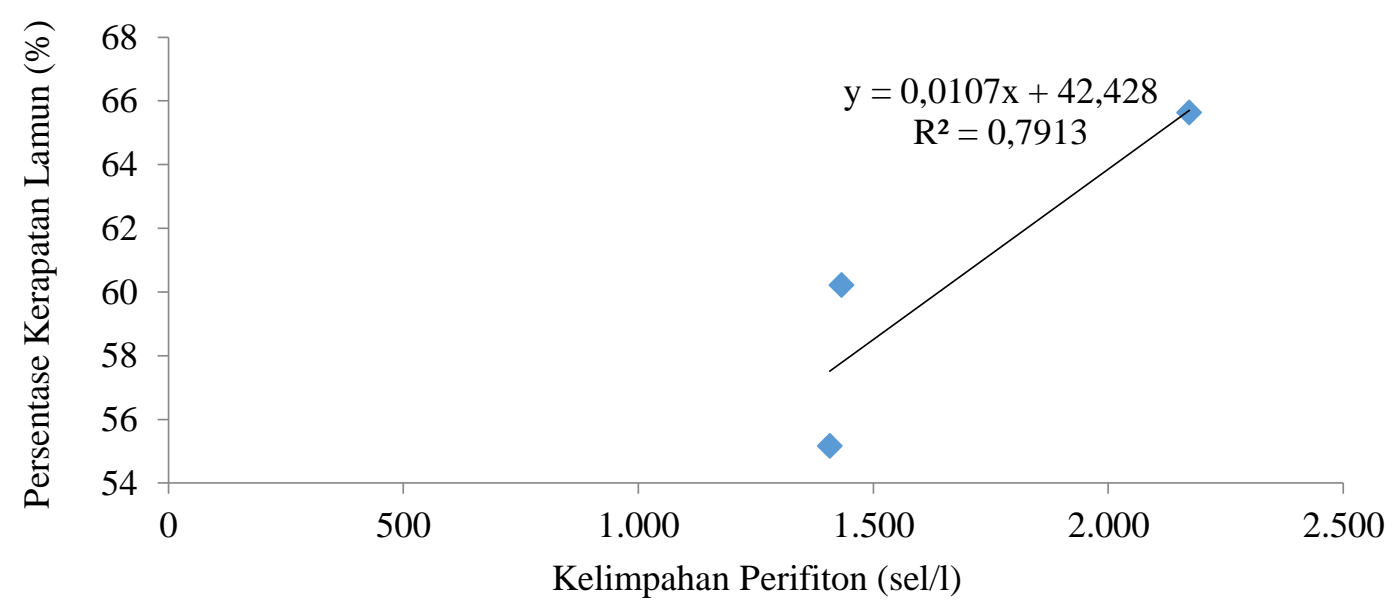

Gambar 3. Kerapatan lamun dan kelimpahan perifiton

\section{Hubungan Kerapatan Lamun dengan Kelimpahan Perifiton}

Kerapatan lamun mempengaruhi 79,13\% kelimpahan perifiton (Gambar 3). Hubungan ini menunjukkan bahwa kerapatan lamun dengan kelimpahan perifiton memiliki hubungan kuat (Usman dan Akbar. 2000). Ritniasih dan Munasik (2017) menemukan kerapatan lamun berbengaruh $68 \%$ terhadap kelimpahan perifiton. Kelimpahan perifiton pada lamun sangat dipengaruhi oleh morfologi dan kerapatan lamun (Herkul dan Kotta, 2009). Bentuk morfologi daun yang lebar dan kerapatan yang tinggi mampu mengurangi pergerakan arus dan mempercepat pengendapan partikel tersuspensi. Lamun dengan daun yang lebar mmeiliki struktur lebih kuat substrat penempelannya lebih stabil (Folkard, 2005). Daun lamun yang semakin lebar memungkinkan peluang penempelan perifiton semakin besar. Panjang tegakan daun dan kerapatan lamun akan mempengaruhi sebaran perifiton pada lamun. Permukaan daun lamun memiliki permukaan daun yang kasar menguntungkan bagi perifiton untuk menempel (Larkum et al., 2006).

$E$. acoroides merupakan lamun dengan tegakan paling tinggi dan biasanya memiliki kerapatan tinggi memiliki pengaruh kuat terhadap kelimpahan perifiton. Lamun dengan daun lebar akan mempermudah dan memperluas habitat penempelan perifiton. Luas permukaan daun lamun berpengaruh pada penempelan perifiton, sehingga kelimpahan perifiton pada permukaan daun berbeda. Daun lamun yang semakin lebar memungkinkan peluang penempelan biofilm semakin besar. Ritniasih dan Munasik (2017) menyatakan bahwa kerapatan E. acorides memiliki hubungan lebih kuat dengan kelimpahan perifiton dibandingkan lamun Cymodocea serrulata. Dengan demikian kerapatan lamun berpengaruh terhadap kelimpahan perifiton pada lamun.

\section{KESIMPULAN}

Perifiton yang ditemukan dalam penelitian ini sebanyak 10 jenis dan jenis Baciliarophyceae merupakan jenis perifiton paling banyak ditemukan. Kelimpahan perifiton paling banyak pada musim peralihan yaitu sebesar $2.146 \mathrm{sel} / \mathrm{l}$. Keanekaragaman jenis perifiton di lamun $E$. acoroides memiliki nilai antara 0,26-1,43 (Keanekaragaman rendah-sedang), keseragaman dengan nilai 3,61-5,82 (keseragaman tinggi) dan dominansi dengan nilai 0,68-1,12 (dominansi sedang-tinggi). Hubungan kerapatan dengan kelimpahan perifiton sebesar $79,13 \%$ yang menunjukkan hubungan kuat. Dengan demikian kerapatan lamun berpengaruh terhadap kelimpahan perifiton pada lamun.

\section{DAFTAR PUSTAKA}

Aparna, M.S. and Yadav, S., 2008. Biofilms: microbes and disease. Brazilian Journal of Infectious Diseases, 12(6):526-530.

APHA (American Public Health Association). 1989. Stadart methods for the examination of water and wastewater. 14th Ed. Amer. Publ. Health. Assoc. Washington DC.

Ario, R., Riniatsih, I., Pratikto, I. \& Sundari, P.M. 2019. Keanekaragaman Perifiton pada Daun Lamun Enhalus acoroides dan Cymodocea serrulata di Pulau Parang, Karimunjawa. Buletin Oseanografi Marina, 8(2):116-122 
Barus, B.S., Aryawati, R., Putri, W.A.E., Nurjuliasti, E., Diansyah, G. \& Sitorus, E. 2019. Hubungan N-Total dan C-Organik Sedimen Dengan Makrozoobentos di Perairan Pulau Payung, Banyuasin, Sumatera Selatan. Jurnal Kelautan Tropis, 22(2):147156

Febriana, H.A., Purnomo, P.W., Suryanti. 2016. Kadar Logam Berat $\mathrm{Pb}, \mathrm{Cd}$ dan Kelimpahan Perifiton Pada Ekosistem Lamun Di Pantai . Buletin Oseanografi Marina, 5(2):107-114

Larkum, A.W.D., Orth, R.J. \& Duarte, C.M. 2006. Seagrasses: Biology, Ecology and Conservation. Springer. Netherlands

Nabilla, S., Hartati, R. \& Nuraini, R.A.T. 2019. Hubungan Nutrien Pada Sedimen dan Penutupan Lamun di Perairan Jepara. Jurnal Kelautan Tropis. 22(1):42-48

Odum, E.P. 1993. Dasar - Dasar Ekologi. Gadjah Mada Univ Press. Yogyakarta. $679 \mathrm{hlm}$.

Orbita, L.S. \& Mukai, H. 2013. Relationship Between Epiphytes And The Photosyntetic Activity Of Temperate Seagrasses. Aab Bioflux, 3(5):163-168
Ritniasih, I. 2016. Distribusi Jenis Lamun Dihubungkan dengan Sebaran Nutrien Perairan di Padang Lamun Teluk Awur Jepara. Jurnal Kelautan Tropis, 19(2):101107

Sakey, W.F., Wagey, B. \& Gerung, G. 2015. Variasi Morfometrik Pada Beberapa Lamun Di Perairan semenanjung minahasa. Jurnal Pesisir Dan Laut Tropis. 1(1):1-7

Sarbini, R., Nugraha, Y. \& Kuslani, H., 2016. Teknik Sampling dan Pengamatan Kelimpahan Perifiton Di Ekosistem Lamun, Kepulauan Karimun Jawa, Jawa Tengah. Buletin Teknik Litkayasa Sumber Daya dan Penangkapan, 13(2):91-96

Siregar, S.H. \& Telaumbanua. K.S. 2010. Variasi Diatom Epifitik (Bacillariophyceae) pada Batang dan Pneuma Tophore Bakau Avicennia sp. di Kawasan Pelabuhan Tanjung Buton. Provinsi Riau. Jurnal Ilmu Lingkungan. 4(1):11-24.

Welch, E.B. 1981. Ecological Effects of Waste water. Cambridge University Press. Cambridge. 337 hlm. 